\title{
Crimes Against Humanity in Iraq: The Case Against Iran
}

\author{
Gabriel Lajeunesse*
}

Institute for the Study of Diplomacy, Georgetown University, 1316 36th St NW, Washington DC 20007, USA

\begin{abstract}
Sectarian violence in Iraq has decreased significantly, but a lack of justice for the victims could rekindle passions. Particularly grave are those violations of human rights and humanitarian law committed by Shia militias sponsored by Iran. This paper finds that there is significant evidence supporting Iranian culpability as an accessory for facilitating, aiding and assisting Shia death squads in their commission of crimes against humanity in Iraq. However, there is insufficient data to determine if Iran exercised the level of control necessary to demonstrate state liability. These are facts that should be determined. To increase the chances of justice and long-term reconciliation, the United Nations Security Council should act now and refer Iran to the Prosecutor of the International Criminal Court for investigation of these alleged crimes.
\end{abstract}

\section{INTRODUCTION}

From February 2006-May 2007, thousands of noncombatants were killed in Iraq in a wave of sectarian violence that placed Iraq on the brink of civil war. Reports suggest that these were not random and uncoordinated actions but rather were orchestrated by Sunni's from al-Qa'ida in Iraq on one hand, and Shi'a death squads on the other. Evidence strongly suggests that the government of Iran provided significant material support to Shi'a death squads which killed thousands of Sunni civilians in Baghdad and its environs from 2006-2007.

If true, Iran and its surrogates committed crimes against humanity and war crimes in Iraq. Victims, and survivors, and Iraqi Sunnis as a whole need justice, healing, and reconciliation-Iran must be held accountable to hasten these goals. International and geopolitical pressures suggest an international tribunal, such as the International Criminal Court, may be the most appropriate forum.

This article reviews the historical context of Iranian support of the Shi'a militias and briefly discusses evidence of Iran's material support to Shi'a death squads. It then outlines the violations of international law-crimes against humanity and war crimes - that this evidence suggest have been committed, and discusses the value of an international over a domestic forum for hearing these cases. This article recommends that an international tribunal, the ICC, begin investigation of the crimes, and then discusses a few of the legal issues the court would face in attributing the crimes to Iran: modes of participation and accessorial responsibility, the doctrine of command responsibility, state responsibility, and the issue of international versus non-international armed conflicts.

\section{BACKGROUND}

Evidence suggests the government of Iran provided material support to Shi'a Death Squads that killed thousands of Sunni civilians in Baghdad and its environs from 2006-2007.
*Address correspondence to this author at the Institute for the Study of Diplomacy, Georgetown University, 1316 36th St NW, Washington DC 20007, USA; E-mail: gcl22@law.georgetown.edu

On 22 February 2006, Al-Qa'ida Iraq (AQI) terrorists attacked one the holiest sites in Shi'a Islam, the al-Askari Golden Mosque in Samarra, Iraq (Knight, 2006). The plan to destabilize Iraq through a Shi'a-Sunni civil war, masterminded by AQI leader Abu-Mu'sab al-Zarqawi, was very much on its way (Stewart, 2004; Howard, 2004). Within days, Shi' a militias began carrying out retaliatory attacks on Sunni civilians, and before long hundreds of bodies were found littered among the streets of Baghdad (Worth, 2006). AQI and these Shi' a death squads increasingly began targeting civilian populations along sectarian lines. By Dec 06/Jan 07 over 2000 civilian deaths per month were reported in Baghdad alone (Petraeus, 2007).

The spike in civilian deaths was not simply a result of the battle between Iraq confessional groups, but rather was financed, staffed, and sponsored by external actors-al-Qa'ida and its foreign fighters and financiers driving AQI behaviors on the one hand and Iran and the Shi' a death squads on the other (Kagan, 2006). Iran's support to Shia death squads contributed to the acceleration of this internecine conflict which placed Iraq on the brink of civil war by early 2007 (Annan, 2006). Iran has historically faced an existential threat from the Arab world in general and Iraq specifically. The thousands of years of human history that pitted Persia against the rulers of Mesopotamian remain a part of the Iranian identity. This cultural propensity for wariness of their Arab neighbors was nothing but strengthened by the experience of the Iran-Iraq War, in which over 200,000 Iranians lost their lives (Iran Chamber, 2008). Iraq's large army and expansionist vision under Saddam Hussein presented the most clear and present danger to the Iranian state prior to the US invasion of Iraq in 2003 (Abedin, 2002).

Additionally, the revolutionary ideology of the Islamic Republic has heightened tensions between Iran and its Sunni Arab neighbors, and has paved the way for interference in the internal affairs of Iraq and countries throughout the region (Holmes, 1993; Philips, 1996). When the Ayatollah Khomeini was swept into power in 1978, it was in response 
to popular discontent with perceived American neocolonialism and the Shah's failed domestic programs. However, the hostage-crisis at the American Embassy provided an opportunity to vilify America and Western values, allowing Khomeini to further consolidate power in the face of this confrontation with the United States (the "great Satan") (Erlich, 2001). Part of this effort to consolidate power was the creation of a parallel structure to the conventional state security apparatus, loyal only to the Supreme Leader. Khomeini created the Islamic Revolutionary Guard Corps (IRGC), to protect the revolutionary government and to export the revolution abroad (Kagan, 2006). The IRGC has its own intelligence/unconventional warfare apparatus (the Qods ForceQF), which reports only to the Supreme Leader (Kagan, 2006). While the Iranian Army, Navy and Ministry of Intelligence and Security (MOIS) continued to operate as the professional security services of the State, IRGC was staffed by hardliners affiliated with the revolution which reported directly to the Supreme Leader (first Khomenie, later Khamenei) (Philips, 2005).

The IRGC-QF was used as the principal arm for exporting the revolution; an effort to help spread the theocratic aims and messianic vision of twelver Shi'asm (Fars News Agency, 2007). IRGC-QF were active throughout the region, recruiting, funding, developing revolutionary cells, and providing terrorist training to like-minded Islamists in places such as Turkey and Lebanon (i.e. Lebanese Hezbollah) (US Department of State, 2007; Cakir, 2007). These cells carried out assassinations, conducted guerilla warfare, and acted as spoilers in the region at the behest of Iran (Flatow v. Islamic Republic of Iran, 1998). These cells also worked to indoctrinate potential followers, conduct charitable activities, and develop a robust network that could one day serve as a vanguard for revolution and establishment of an Islamic state (Cakir, 2007).

The IRGC-QF have long worked among Iraqi Shi' a dissidents. From among Iraqi Shi'a, the IRGC-QF formed a number of revolutionary organizations using their well established methodology-the Supreme Council for Islamic Revolution Iraq-Badr Corps, 15 Shaban, and Iraqi Hezbollah to name the most prominent (Shafa, 2008). These organizations would infiltrate back into Iraq to conduct intelligence and other special operations such as the assassinations of Ba' ath Party officials (Ford, 2003).

The US Invasion of Iraq in 2003 provided a moment of pause for Iran. While displacing its mortal enemy through the ousting of Saddam, Iran was now seemingly surrounded by the "Great Satan"-with large concentrations of US forces in border states of Iraq and Afghanistan and nearby in the Gulf. As a member of the group of nations described by President Bush as the "axis of evil", American intervention and regime change may have seemed imminent (Burnett, 2007). The unclassified National Intelligence Estimate notes that Iran stopped its uranium enrichment for a time in 2003 - probably not a coincidence (Director of National Intelligence, 2007).

To secure their interests, Iran sent hundreds of surrogates into Iraq in the early days of the US occupation (Pound, 2004). As the new political situation unfolded in Iraq, it became apparent that there was a disconnect between the Iraqi expatriates recently returned from Iran and the "man on the street" in many Shi' a communities. The former exiles, like SCIRI leader Abdul Aziz al-Hakim, were seen as outsiders in contradistinction to those, like Radical Shi'a Cleric Mukhtada al-Sadr, who had stayed in Iraq during the Shi' a purges and had suffered through the persecution of Fedayeen Saddam and other Baath Party security organs. Sadr, vocally opposed to the US occupation, saw a meteoric rise in popularity. Iran, in an apparent effort to cover all its bases, began building a relationship with Sadr and his make-shift militia, the Jaysh al-Mahdi (JAM): "The Iranians have pursued a two-track intervention in Iraq. On the one hand, they have supported the Shiite political and religious establishment, which has endorsed Iraq's transition to democracy and cooperated with the coalition, while on the other hand, they have supported Sadr, who has challenged the Shiite establishment and tried to mobilize the Shiite community against the occupation" (Gambill, 2004).

By early 2004, Sadr and the JAM were receiving training in Iran by IRGC-QF and had established a relationship with Lebanese Hezbollah (LH), working to develop an organization modeled on the LH; Mustafa al-Sheibani was responsible for developing this network of IRGC sponsored insurgent with the express purpose of committing violence against coalition forces in Iraq (Kagan, 2007). "Sheibani's team consist[ed] of 280 members, divided into 17 bomb-making teams and death squads" (Ware, 2005). Those receiving this training became the basis for the JAM "Special Groups" (Kagan, 2005).

In March of 2004, US forces arrested Sadr Lieutenant Mustafa al-Yaqubi for the murder of rival cleric Abdul Majid al-Khoei (Coalition Provisional Authority, 2004). Sadr himself was implicated in the murder, and an arrest warrant was issued; rather than turn himself-in, Sadr choose to show his strength (Coalition Provisional Authority, 2004). In a series of uprisings from March-August 2004, JAM forces rose in southern Iraq, repeatedly occupied government offices, attacked coalition officials, and took control of cities at will including Basra, Nasiriyah, Najaf, and al-Kut, often for several days at a time (Shanker and Schmitt, 2004). During the course of these uprisings, Iran was reported to be re-supplying the JAM forces with munitions. In one significant incident, over 60 mortar rounds were dropped on the Coalition Provisional Authority office in Nasiryah (Cappelli, 2005). Similar attacks occurred throughout Southern Iraq. The stand-off with JAM in the summer of 2004 finally ended when coalition and Iraq forces surrounded Sadr in Najaf and a truce was negotiated (Barnard, 2004).

Though JAM elements no longer openly controlled the streets in Southern Iraq, attacks against coalition forces continued. JAM Special Groups trained by Iran and LH began using explosively formed penetrators (EFPs), improvised explosive devices designed to defeat the armor of coalition vehicles to attack coalition forces; groups/cells between 20-60 were trained in use of "EFPs, mortars, rockets, as well as intelligence, sniper, and kidnapping operations" (Kagan, 2007). The EFP's, mortar and rocket attacks against coalition forces by the Special Groups used material provided by Iran, many with markings indicating recent manufacture (Bergner, 2007). By early 2006, the Special Groups were organized into a Hizbullah-style 
structure, with Iraqi Qais Khazili as head of all the Special Groups with a reporting chain directly to Hajji Yusif, the Deputy Commander of IRGC-QF (Kagan, 2007). IRGC-QF provided between $\$ 750,000$ and $\$ 3$ million in funding and equiptment to the Special Groups each month (Kagan, 2007).

While Special Groups may have been involved in extrajudicial killings prior to the Samarra bombing, the scale of their activities increased exponentially in the months following - these attacks were often attributed to "rogue JAM elements" (Multi-National Forces Iraq, 2007). As these attacks increased, what are assumed to have been Special Groups actors began operating in a more brazen manner. Masked JAM gunmen patrolled the streets of Baghdad stopping vehicles to search for Sunnis and pulling them from storefronts. Those found were gathered together in groups and executed in the street, many times in front of their children, traumatizing a whole generation of young Iraqis (Guardian, 2006). In addition to these daily murders, homes were set on fire in what was described as an effort to drive Sunni residents out of the neighborhood and secure Shi'a hegemony (Guardian, 2006). In the JAM stronghold of Sadr City, Special Groups established a extra-judicial Sharia Court, where it would try Sunni's, execute them, and then dump their bodies in the street (Guardian, 2006).

Though the perpetrators of individual incidents are not known, Kimberly Kagan's report on the subject indicates that Special Groups were directly involved in the turmoil in Iraq in 2006 and 2007, contributing "vigorously to the sectarian violence that plagued Iraq...[as they] organized and facilitated death squads..." (Kagan, 2007).

According to Ken Pollack, leading Iranian expert and Senior Fellow at the Brookings Institute, evidence of Iranian support to Special Group's involved in ethnic cleansing was overwhelming, with weapons recovered showing recent manufacturer and local sources all citing regular Iranian support: "it is clear that Qods Forces did a tremendous amount of encouraging, training, equipping, were probably involved in facilitating and maybe even participating"-but of the latter it is harder to find evidence (Pollack, 2008). If the ICC did investigate they might have a better chance of determining the extent of Iranian participation (Pollack, 2008). According to Pollack, however, Iran clearly provided material support to these efforts - they knew what the Special Groups were doing and understood what the weapons, materials, and funds provided were being used for (Pollack, 2008).

Michael Eisenstat, Fellow and Director for Military Studies at the Washington Institute for Near East Policy, agrees that there is consistent reporting on Iranian support to the JAM all the way to 2004, and possibly even payments by Iran to instigate sectarian violence, but feels that it would be very difficult to attribute specific command and control with existing evidence-current evidence shows money, training, equipment has been regularly and consistently provided, but further investigation is needed to determine anything more (Eisenstadt, 2008).

\section{JUSTICE FOR THE VICTIMS}

Evidence suggests that Iran and its surrogates committed crimes against humanity and war crimes in Iraq. Iraq is in need of both justice and healing-while domestic actors could be handled by Iraqi courts, the international and geo- political pressures suggest an international tribunal may be the most appropriate forum.

\section{What are the Possible Charges?}

Given the facts as presented, what recourse do the victims of Iranian-sponsored violence have? What violations of law do these actions represent? The accounts discussed suggest that the atrocities committed by Iranian sponsored Shi' a death squads include many crimes against humanity: murder, deportation or forcible transfer of population, imprisonment or other severe deprivation of physical liberty, torture, persecution, enforced disappearance of persons, apartheid, other inhumane acts (ICC Elements of Crimes, 2008). Further investigation is needed to secure proof of these crimes and possibly establish others. In order to establish these crimes as "crimes against humanity", it must be shown that the conduct was committed as part of a widespread or systematic attack directed against a civilian population and that the perpetrator knew that the conduct was part of this widespread or systematic attack (ICC Elements of Crimes, 2008).

Iran may also be prosecuted for violations of the laws of war. Charges would vary depending upon whether the conflict is determined to be an international armed conflict or non-international armed conflict (to be discussed further below). If this is determined to be an international armed conflict, there may be sufficient evidence to support charges of the following war crimes: willful killing, torture, inhumane treatment, causing great suffering, destruction and appropriation of property, denying a fair trial, unlawful deportation and transfer, unlawful confinement, taking hostages, attacking civilians, attacking civilian objects, attacking personnel or objects involved in a humanitarian assistance or peacekeeping mission, excessive incidental death, injury, or damage, attacking undefended places, killing or wounding a person hors de combat, mutilation, pillaging, outrages upon personal dignity, rape, sexual violence, using, conscripting or enlisting children (ICC Elements of Crimes, 2008). If the conflict is found to be non-international in nature, there may be sufficient evidence to support charges for war crimes specifically prohibited in non-international armed conflicts (ICC Elements of Crime, 2008). It would have to be shown that these crimes had not only been committed, but also by whom. In the event these crimes were committed by groups sponsored by Iran, the command and control relationship between Iran and the groups would also need to be demonstrated. Discussion of Iran responsibility for acts of its proxies will be discussed further below.

\section{What is the Proper Forum?}

Though Iraqi courts could try individual actors responsible for these crimes the likelihood that justice could be provided in a non-sectarian manner and a way that enhances reconciliation is unlikely. According to Steven R. Perles, leading trial lawyer representing victims of international terrorism, cases in domestic courts are inherently impacted by politics, as government leaders exert pressure to ensure politically expedient outcomes (Perles, 2008). This can have exactly the opposite of the desired effect, inflicting greater emotional trauma on the victims and survivors. Additionally, domestic rules of evidence may preclude the transparency of the proceeding, decreasing the value of the proceedings in the process of reconciliation (Perles, 2008). In these circum- 
stances, an international tribunal may serve as a better venue than domestic courts. The International Criminal Court, a standing tribunal developed for just this type of circumstance, would serve as a powerful forum for this case. Ensuring justice is part and parcel of the rationales for the establishment of the International Criminal Court:

Mindful that during this century millions of children, women and men have been victims of unimaginable atrocities that deeply shock the conscience of humanity...

Recognizing that such grave crimes threaten the peace, security and well-being of the world,

Affirming that the most serious crimes of concern to the international community as a whole must not go unpunished and that their effective prosecution must be ensured by taking measures at the national level and by enhancing international cooperation,

Determined to put an end to impunity for the perpetrators of these crimes and

thus to contribute to the prevention of such crimes (Rome Statute of the International Criminal Court (2002).

Investigation of this case by the ICC prosecutor would allow a clearer picture to emerge regarding the exact nature of the crimes and the extent of Iranian involvement. The ICC provides a venue with greater transparency and decreased likelihood of politically motivated/expedient outcomes.

However, regardless of the forum, there will be significant legal issues to resolve to establish Iranian culpability for the crimes committed by Shi'a death squads in Iraq.

\section{ISSUES OF LA W}

There are a number of overarching legal issues that must be addressed to determine the responsibility of Iran for the alleged crimes. While it is impossible to determine how a court would rule without additional facts about the incidents, we can outline the standards courts may consider when examining these issues. Here we examine a few issues related to Iran's culpability-modes of participation and accessorial responsibility, the doctrine of command responsibility, state responsibility, and the issue of international versus noninternational armed conflicts.

\section{Modes of Participation-Accessorial Responsibility}

There is no evidence to suggest that Iranian officials were principals in commission of any crimes against Iraqi civilians. While this is possible, Iran is notorious for its use of proxies in carrying out acts of terrorism, so as to escape attribution (Rice, 2008). Iranian officials, if liable under international criminal law, are probably liable for being complicit in the crimes of the Shi' a death squads. The court will have to determine whether Iranian officials meet the threshold for assignment of responsibility as an accessory:

\section{ICC Statute, Article 25: Individual Criminal Responsibility}

3. In accordance with this Statute, a person shall be criminally responsible and liable for punishment for a crime within the jurisdiction of the Court if that person: (a) Commits such a crime, whether as an individual, jointly with another or through another person, regardless of whether that other person is criminally responsible;

(b) Orders, solicits or induces the commission of such a crime which in fact occurs or is attempted;

(c) For the purpose of facilitating the commission of such a crime, aids, abets or otherwise assists in its commission or its attempted commission, including providing the means for its commission;

(d) In any other way contributes to the commission or attempted commission of such a crime by a group of persons acting with a common purpose. Such contribution shall be intentional and shall either:

(i) Be made with the aim of furthering the criminal activity or criminal purpose of the group, where such activity or purpose involves the commission of a crime within the jurisdiction of the Court; or

(ii) $\mathrm{Be}$ made in the knowledge of the intention of the group to commit the crime;,.. (Emphasis added to highlight description of accessorial liability) (Rome Statute of the International Criminal Court, 2002).

Here the ICC identifies a number of modes of participation other than the principal actor: one who induces, one who facilitates, aids, abets or otherwise assists, or one who contributes to commission of a crime by a group acting with a common purpose.

Assignment of criminal liability will require showing Iranian officials committed an illegal act (actus reus) with proper criminal intent (mens rea).

The question of whether Iranian officials can be held liable for their actions in support of Shi'a death squads requires: 1) an assessment of whether their action or inaction (dereliction of duty) - actus reuswas sufficient to make them liable as an accomplice, and 2) an assessment of whether the mental state of these officials at the time of these actions-mens rea-was such that they may be held criminally liable as an accomplice (Luban, O'Sullivan and Stewart, forthcoming).

The ICC has yet to develop a body of jurisprudence to draw from in judging these factors, but other international tribunals have examined similar issues, and these decisions will probably inform the ICC in dealing with accessorial liability in its own cases. We will examine some of these rulings in considering the actus reus and mens rea for each of the ICC's accessorial modes of participation. In addition to specific mens rea requirements described below, the ICC has defined the metal element as follows:

Article 30

\section{Mental Element}

1. Unless otherwise provided, a person shall be criminally responsible and liable for punishment for a crime within the jurisdiction of the Court only if the 
material elements are committed with intent and knowledge.

2. For the purposes of this article, a person has intent where:

(a) In relation to conduct, that person means to engage in the conduct;

(b) In relation to a consequence, that person means to cause that consequence or is aware that it will occur in the ordinary course of events.

3. For the purposes of this article, "knowledge" means awareness that a circumstance exists or a consequence will occur in the ordinary course of events. "Know" and "knowingly" shall be construed accordingly (Rome Statute of the International Criminal Court, 2002).

We will now review the ICC's accessorial modes of participation: one who induces, facilitates/aids/abets, or contributes to a group with a common [criminal] purpose.

\section{Inducing the Commission of a Crime}

What does it mean to induce crimes against humanity or war crimes? The International Criminal Tribunal for Yugoslavia (ICTY) and the International Criminal Tribunal for Rwanda, used the term "instigate" rather than "induce", identifying as criminally responsible a "person who planned, instigated, ordered, committed or otherwise aided..."(Statute of the International Criminal Tribunal for Yugoslavia; Statute of the International Criminal Tribunal for Rwanda). Though there are slight differences in meaning between the terms, the ad-hoc tribunals standard for instigating will probably inform the ICC's view on the inducement as well.

To satisfy the actus reas for instigating, the accused must have prompted the person committing the crime to act in the criminal manner; this prompting must be a clear contributing factor (Prosecutor v Kvocka, 2001).

To satisfy the mens rea for instigating, the accused must have intended to induce the party to commit the criminal act or be aware of the criminal acts substantial likelihood as a result of the accused's instigation.

Here it would have to be shown that Iranian officials training, equipping and tasking of Shi'a death squads prompted them to carry out the crimes they committed against Sunni non-combatants in Iraq. It is not clear that this is the case, but further investigation is necessary-for example, did training of the death squads include scenarios on attacking civilian populations, were material and equipment specifically designed for use against civilian targets, or did taskings from Iranian officials prompt, encourage or incite such acts?

Additionally, it would have to be shown that whatever training, equipment or taskings given were either intended to induce those crimes, or that they were substantially likely as a result of this training, equipping and tasking.

Based upon the information available at this time, it is unlikely that Iran would be found responsible as an inducer of the crimes of the Shi' a death squads.

\section{Facilitates, Aids, Abets or Otherwise Assists}

The 2001 ICTY decision in Prosecutor v Kvocka described the standard for aiding and abetting as practical assistance, moral support or encouragement that has a substantial effect on commission of crime. It is also possible to aid or abet by omission if the omission has a significant effect on commission of crime. The 1998 ICTR decision in Prosecutor $v$ Akeyesu found that aiding and abetting are two different modes of participation - to aid is to assist, to abet is to facilitate by being sympathetic to the crime.

The Kvocka court defined mens rea as knowledge that these acts assist or facilitate commission of a crime, they do not need to share the intent of perpetrator. The 1998 ICTY decision in Prosecutor v Aleksovski highlighted that the aider and abettor must be aware of the crime of the principal.

Mens Rea can be implied, “...if the criminal enterprise entails killing members of a particular ethnic group, and members of the ethnic group were of a differing religion, race or political group than the co-perpetrators, that would demonstrate an intent to discriminate on political, racial or religious grounds. Thus a knowing and continued participation in this enterprise could evince an intent to persecute members of the targeted ethnic group" (Prosecutor v Aleksovski, 1998).

Here it would have to be shown that Iranian officials provided practical assistance and support that had a substantial impact on the commission of the crime, and further that they knew that this assistance would in fact facilitate the attacks on Sunni non-combatants by the Shi'a Militias they supported. While additional evidence of specific crimes is needed, the current body of evidence suggests that Iranian official have provided training and material assistance to Shi'a death squads, and that this training and assistance enabled the actions. While it is unknown whether Iran anticipated their aid would be used to carry out attacks against civilian populations when the attacks first occurred after the Golden Mosque bombing in Feb 06, there can be little doubt that they became aware as these events unfolded. The sectarian murders and wanton attacks on civilian populations were daily headlines for over a year. Continued support, training and resupply to the Shi' a death squads while they continued their campaign against Sunni non-combatants in Baghdad implies sufficient mens rea existed.

Based upon the information available at this time, it is probable that Iranian officials could be found as accessories for having facilitated, aided, and abetted the crimes of the Shi'a death squads.

\section{Contributes to Crime of a Group with a Common Pur- pose}

This mode of participation in the ICC codifies the theory of joint criminal enterprise (JCE) utilized in the ad-hoc tribunals. Under JCE theory a person is criminally liable if they participated in the execution of a criminal plan commonly held by a plurality of persons (Prosecutor v Tadic, 1997). Those who assist in a significant way, or are in such a position of authority that this assistance can be presumed, have sufficient actus reas to be held criminal liable (US v Ohlendorf, et al, 1947). The test is whether the accused's participation made the crimes easier, more efficient to commit (The 
Stalag Luft III Case, 1949). Required mens rea is a knowledge that their actions were assisting in carrying out a criminal act (Kiel Gestapo Case, 1947).

Thus, for Iranian officials to be liable for contributing to the crime of a group with a common purpose, it would need to be shown that a criminal group with a common purpose existed-i.e. Shi' a death squads with a goal of murdering, intimidating, and driving Sunni non-combatants from Baghdad. It would then need to be shown that the officials knowingly assisted in the commission of the plan. Currently it is not clear if the various Shi' a death squads operated with a common coordinated purpose, or if these were acts of individuals that rapidly got out of control as the situation deteriorated. It seems logical that there was a coordinated effort, but evidence would have to be found to prove this. If proven, as in the case of aiding abetting, it is probable that Iranian officials could be found as contributing to a common criminal purpose of these groups due to the material support provided throughout the duration of the event.

\section{Command/Superior Responsibility}

Another theory of criminal responsibility related to modes of participation, is that of command responsibility. Tribunals from Nuremberg on have recognized the theory that commanders and superiors can be liable for the criminal acts of subordinates. Thus, though other modes of participation may not be proven, a commander assumes criminal liability for atrocities committed by troops under his command that the commander knew about, but did not take necessary and reasonable measures to prevent (Luban et al, forthcoming).

Cases from the ad-hoc tribunals may shed light on how the command responsibility doctrine may be interpreted in the ICC. The Celebici cases at the ICTY discussed whether command responsibility could be attributed to those leaders that directly influenced the events in question but were not in the official chain of command (i.e. de facto commanders) (Prosecutor v Delalic, 1998). The court held that regardless of whether de facto or de jure, the commander-subordinate relationship is established when one has the material ability to prevent or punish criminal conduct, however that control is exercised. The Celebici court also established mens rea as sufficient when the commander knew or had reason to know that the subordinate was committing crime (Prosecutor $v$ Delalic, 1998). A 2004 ICTY case, Prosecutor v. Blaški, established that a commander may not be convicted for negligent supervision or for a failure to put in place an effective reporting system, unless he or she did this through willful blindness-i.e. it is generally not enough that the commander "should have known", he or she must actually have known about the crimes or have purposely evaded knowing of them. However the ICC does seem to include a negligence standard for military commanders, defaulting to the Blaski standard for civilians.

The ICC statute incorporate the command responsibility doctrine via Article 28 of its statute:

\section{Article 28}

\section{Responsibility of Commanders and Other Superiors}

In addition to other grounds of criminal responsibility under this Statute for crimes within the jurisdiction of the Court: (a) A military commander or person effectively acting as a military commander shall be criminally responsible for crimes within the jurisdiction of the Court committed by forces under his or her effective command and control, or effective authority and control as the case may be, as a result of his or her failure to exercise control properly over such forces, where:

(i) That military commander or person either knew or, owing to the circumstances at the time, should have known that the forces were committing or about to commit such crimes; and

(ii) That military commander or person failed to take all necessary and reasonable measures within his or her power to prevent or repress their commission or to submit the matter to the competent authorities for investigation and prosecution.

(b) With respect to superior and subordinate relationships not described in paragraph (a), a superior shall be criminally responsible for crimes within the jurisdiction of the Court committed by subordinates under his or her effective authority and control, as a result of his or her failure to exercise control properly over such subordinates, where:

(i) The superior either knew, or consciously disregarded information which clearly indicated, that the subordinates were committing or about to commit such crimes;

(ii) The crimes concerned activities that were within the effective responsibility and control of the superior; and

(iii) The superior failed to take all necessary and reasonable measures within his or her power to prevent or repress their commission or to submit the matter to the competent authorities for investigation and prosecution" (Rome Statute for the International Criminal Court, 2002). (Emphasis added)

Here, to establish the commander-subordinate relationship, it would have to be shown that Iranian officials actually had the ability to prevent or punish conduct of the Shi'a death squads. There is not enough information at this time to fully appreciate the relationship Iranian officials had with the Shi'a death squads. Further investigation is needed to determine whether Iranian orders would be obeyed or if they could effectively punish the death squads. The mens rea requirement, that Iranian officials knew of the conduct, cannot be seriously doubted given the press coverage of the events.

\section{State Responsibility}

Beyond the issue of individual criminal responsibility is the question of State responsibility. Is the Government of Iran, through its support of Shi'a death squads, responsible for the atrocities committed by them and thus liable for reparations to the Government of Iraq? Probably not. Such state to state disputes are handled by the International Court of Justice (ICJ); the ICJ's 1986 ruling in Nicaragua v Unites States is dispositive, where it determined that US support and sponsorship of the Contra rebels did not result in US responsibility for that group's action against Nicaragua. 
The Nicaragua court considered state support of a group to be insufficient to establish state responsibility. To be attributable, the ICJ required that the state control the private actor that caused the damage, and a showing that the private actor is dependent upon the state:

The Court has to determine whether the relationship of the contras to the United States Government was such that it would be right to equate the contras, for legal purposes, with an organ of the United States Government, or as acting on behalf of that Government. The Court considers that the evidence available to it is insufficient to demonstrate the total dependence of the contras on United States aid. A partial dependency, the exact extent of which the Court cannot establish, may be inferred from the fact that the leaders were selected by the United States, and from other factors such as the organisation, training and equipping of the force, planning of operations, the choosing of targets and the operational support provided. There is no clear evidence that the United States actually exercised such a degree of control as to justify treating the contras as acting on its behalf. Having reached the above conclusion, the Court takes the view that the contras remain responsible for their acts, in particular the alleged violations by them of humanitarian law. For the United States to be legally responsible, it would have to be proved that that State had effective control of the operations in the course of which the alleged violations were committed (Nicaragua v. U.S., 1986). (Emphasis added)

The ICTY adopted a more expansive view, holding that state responsibility, which they were reviewing to determine whether there was an international armed conflict and thus violations of the law of war, attached when a State has a role in organizing, coordinating or planning a paramilitary group:

Under international law it is by no means necessary that the controlling authorities should plan all the operations of the units dependent on them, choose their targets, or give specific instructions concerning the conduct of military operations and any alleged violations of international humanitarian law. The control required by international law may be deemed to exist when a State (or, in the context of an armed conflict, the Party to the conflict) has a role in organizing, coordinating or planning the military actions of the military group, in addition to financing, training and equipping or providing operational support to that group. Acts performed by the group or members thereof may be regarded as acts of de facto State organs regardless of any specific instruction by the controlling State concerning the commission of each of those acts. Of course, if, as in Nicaragua, the controlling State is not the territorial State where the armed clashes occur or where at any rate the armed units perform their acts, more extensive and compelling evidence is required to show that the State is genuinely in control of the units or groups not merely by financing and equipping them, but also by generally directing or helping plan their actions (Prosecutor v. Tadić, 1999). (Emphasis added)
However, in a subsequent decision by the ICJ, that court rejected the ICTYs expanded conception of state responsibility, indicating that the test may be appropriate for determining whether a conflict is international in nature, but not for assignment of responsibility (Bosnia and Herzegovina $v$. Serbia and Montenegro, 2007).

Here, it would be necessary to show that Iran had sufficient command and control- that the Shi'a death squads essentially became an organ of the Government of Iran. Additional investigation is required to determine the exact command relationship between Iran and the Shi' a death squads. Based on the information currently available, Iran would probably not be held responsible if the dispute was brought before the ICJ (Cassese, 2007).

\section{CONCLUSION}

Shi'a death squads committed crimes against humanity and war crimes against Sunni's in Baghdad and its environs. Iranian support significantly aided the death squad activities. There can be little doubt that Iran knew how their support was being used, yet continued to provide funds, training and weapons throughout the duration of the sectarian violence in Iraq. Iran is probable liable as an accessory in these crimes. It is quite possible that further investigation will reveal a more significant command and control relationship and further implications under a command responsibility doctrine, joint criminal enterprise doctrine, or even principal liability. In that instance, Iran may be liable for reparations to Iraq under a state liability theory.

The United Nations Security Council should act decisively on this evidence and refer the matter to the prosecutor of the International Criminal Court for further investigation. Iran must be held accountable for the crimes they have committed. Victim and survivors need to see their story told. Such an accounting will hopefully hasten reconciliation, providing Iraqi Sunni a sense of hope, acceptance and path back towards a unified Iraq.

With international attention focussed on the crimes, Iran may come to realize the seriousness of their actions and be deterred from these types of activities in the future. Likeminded states observing the ICC investigation may be deterred from sponsoring murder and ethnic cleansing.

The UNSC should take a stand for justice by referring this case to the ICC immediately.

\section{REFERENCES}

Abedin, M. (2002). Iranian Views on Regime Change in Iraq. Retrieved July 31, 2008, from http://www.meib.org/articles/-0211_ir1 html

Annan, K. (2006). UN Secretary General Comments. Retrieved July 31, 2008, from http://news.bbc.co.uk/2/hi/middle_east/6190274.stm

Army Field Manual. 27-10. (1956). The Law of Land Warfare. United States Army.

Barrnard, A. (2004). Sistani, Sadr Negotiate A Truce In Najaf, Violence Mars Pullout Agreement, the Boston Globe.

Bergner, K. (2007). Multi-National Force - Iraq Press Statement. Retrieved July 31, 2008, from http://www.mnf-iraq.com/index. php?option= com_content\&task=view\&id=12641\&Itemid=131

Bosnia and Herzegovina v. Serbia and Montenegro. (2007). International Court of Justice, Judgement 26 February 2007, Para 402-407.

Burnett, A. (2007). Nuclear Ambitions, British Broadcasting Company.

Cakir, R. (2007). The Reemergence of Hizballah in Turkey, Washington Institute for Near East Policy.

Cappelli, R. (2005). Iraq: Italian Lessons Learned, Military Review. 
Cassese, A. (2007). Notes from the President, Burdens of Proof, European Journal of International Law. Retrieved July 31, 2008, from http://www.asil.org/newsletter/president/pres070 625.html

Coalition Provisional Authority. (2004). Arrest Warrant Issued for Iraqi Shi'ite Cleric al-Sadr. Retrieved July 31, 2008, from http://www. iraqcoalition.org/pressreleases/20040405_Sadr_arrest.html

Director of National Intelligence. (2007). National Intelligence Estimate on Iran. Retrieved July 31, 2008, from http://www.dni.gov/press_ releases/20071203_release.pdf

Eisenstadt, M. (2008). Interview with author, Washington Institute for Near East Policy.

Erlich, R. (1999). Interview: Remembering the Hostage Crisis. Retrieved July 31, 2008, from www.iranproject.org/radio/transcript $1 . h t m l$

News, F. (2007). Statement by Chief Justice. Retrieved July 31, 2008, from http://english.farsnews.com/newstext.php?nn=8606190507

Flatow v. Islamic Republic of Iran. (1998). 999 F. Supp. 1, 5 (D.D.C. 1998). Peter, F. (2003). The Men Who Shot Uday Hussein First Inside Account of a 1996 Ambush that Signaled Active Iraqi Resistance, Christian Science Monitor.

Gambill, G. C.(2004). Iran, Sadr, and the Shiite Uprising in Iraq, Middle East Intelligence, Vol. 6(4).

Holmes, S. (1993). Iran's Shadow; Fundamentalism Alters the Mideast's Power Relationships, New York Times.

Howard, M. (2004). Festival Time in Iraq. But by the End of the Day 220 Lay Dead, Guardian.

International Committee of the Red Cross. (2008). How is the Term "Armed Conflict" Defined in International Humanitarian Law?, Opinion Paper. Retrieved July 31, 2008, from http://www.icrc.org/web/eng/siteeng0. nsf/htmlall/armed-conflictarticle-170308/\$file/Opinion-paper-armed-conflict.pdf

International Criminal Court (ICC). (2001). Elements of Crimes. Retrieved July 31, 2008, from http://www.icc-cpi.int/library/-about/officialjournal/Element_of_Crimes_English.pdf

Iran Chamber. (2008). History, Iran-Iraq War. Retrieved July 31, 2008, from http://www.iranchamber.com/history/iran_iraq_war/iran_iraq war1.php

Iraq Violence: Shi'a Massacre Revives Fears of Civil War:(2006). Mahdi Army Blamed for Baghdad Street Slaughter: Shi'as Killed as Car Bombs Explode Near Mosque. The Guardian.

Kagan, K. (2007). Iran's Proxy War against the United States and the Iraqi Government, The Weekly Standard.

Kiel Gestapo Case. (1947). Law Reports of Trial of War Criminals, United Nations War Crime s Commission, Vol. 11

Knight, S. (2006). Bombing of Shi'a Shrine Sparks Wave of Retaliation, Times.

Luban, D. (2009 forthcoming). Manuscript Chapter 18, on file with authors, International and Transnational Criminal Law, Aspen Publishing.

Multi-National Corps - Iraq Public Affairs Office. (2007). U.S. Special Forces Battle Insurgents, Kill 8 Terrorists, Camp Victory, Release No. 20070820-06. Retrieved July 31, 2008, from http://www.mnfiraq.com/index.php?option=com_content\&task=view\&id=13437\&I temid $=21$

Nicaragua v. U.S. (1986). 1986 I.C.J. 15, 63. Perles, S. R. (2008). Interview with author, Washington DC. David, P. (2007). Commander,
Multi-National Forces Iraq testimony to United States -Congress. Retrieved July 21, 2008, from http://www.mnf-iraq.com/images/CGs_Messages/14_070911_gen_petraeus_congress_slides.pdf

Philips, J. (1996). Testimony presented before the House Committee on International Relations, Subcommittee on International Operations and Human Rights.

Philips, J. (2005). Historical Iran, Heritage Foundation. Retrieved July 31, 2008, from http://www.heritage.org/Research/Iran/em977.cfm

Pollack, K. (2008). Interview with author, Washington, DC.

Pound, E. T. (2004). The Iran Connection, US News and World Reports.

Prosecutor v Akeyesu. (1998). ICTR 2 Sep 1998, Case No.ICTR-96-4-T.

Prosecutor v Aleksovski. (1998). ICTY, 25 Jun 1998, Case No. IT-95-14/1.

Prosecutor v. Bla??ki. (2004). ICTY, Case No. IT-95-14-R.

Prosecutor v Delalic. (1998). ICTY, Case No. IT-96-21-I.

Prosecutor v Kvocka. (2001). ICTY 2 Nov 2001, Case No. IT-98-30/1-T.

Prosecutor v Tadic. (1997). ICTY, 7 May 1997, Case No. IT-94-1.

Prosecutor v. Tadi??. (1999). Case No. IT-94-1, Appeals Chamber, Judgment (Merits).

Protocol Additional to the Geneva Conventions of 12 August 1949. (1949).

Protocol II, Relating to the Protection of Victims of Non-International Armed Conflicts. (1977, June 8).

Rice, C. (2008). Comments by US Secretary of State on Hamas as an Iranian proxy. Retrieved July 31, 2008, http://www.inthenews.co.uk/News/autocodes/countries/afghanistan/rice-hamasmilitants-actingas-irans-proxy-warriors- $\$ 1220896 . h t m$

Rome Statute for the International Criminal Court. (2002). Retrieved July 31, 2008, from http://www.icc-cpi.int/library/about/officialjournal/Rome_Statute_English.pdf

Shefa, R. (2008). Iranian Regimes Involvement in Iraq. Retrieved July 31, 2008 from http://www.ncriran.org/index2.php?option=com_content $\&$ do $p d f=1 \&$ id $=5024$

Shanker, T., \& Schmitt, E. (2004) The Reach Of War: The Military; Army Used Speed and Might, Plus Cash, Against Shiite Rebel, New York Times.

The Stalag Luft III Case. (1949). Case \#60, Trial of Max Wieben and 17 others.

The Stalag Luft III Case, British Military Court Reports. (1949). Hamburg, Germany, Trial of War Criminals, The United Nations War Crimes Commission Vol. XI, London, HMSO.

Statute of the International Criminal Tribunal for Yugoslavia. (2000). Article $7(1)$.

Statute of the International Criminal Tribunal for Rwanda. (1994). Article $6(1)$.

Stewart, J. (2004). Iraq Attack Kills 170. Retrieved January 2, 2009, from http://www.abc.net.au/lateline/content/2004/s1058403.htm. US

U.S. Department of State. (2007). Country Reports on Terrorism. Retrieved July 31, 2008, from http://www.state.gov/s/ct/rls/crt/2007/-103711. $\mathrm{htm}$

U.S. v Ohlendorf (Case No 9) (aka the Einsatzgruppen cases). (1948). Trials of War Criminals before the Nuremburg Military Tribunals.

Ware, M. (2005). Inside Iran's Secret War for Iraq, Time Magazine.

Worth, R. F. (2006). Blast Destroys Shrine in Iraq, Setting Off Sectarian Fury, New York Times.

(C) Gabriel Lajeunesse; Licensee Bentham Open.

This is an open access article licensed under the terms of the Creative Commons Attribution Non-Commercial License (http://creativecommons.org/licenses/by-nc/3.0/) which permits unrestricted, non-commercial use, distribution and reproduction in any medium, provided the work is properly cited. 